\title{
Latex Harvesting Technologies Adapted to Hevea brasiliensis Muell Clones GT 1; RRIC 100 and BPM 24 Arg. (Euphorbiaceae) belonging to the Moderate Metabolism Class in the Socio-economic Context of Côte d'Ivoire
}

\author{
Moussa Diarrassouba, Souleymane Sanogo, Brahima Camara, and Samuel Obouayeba
}

\section{ABSTRACT}

Improving the productivity of rubber trees has always been a major concern for rubber farmers. The majority of growers opt for overexploitation of the trees. This disturbs the physiological balance of the rubber trees, which leads to the recrudescence of tapping panel dryness and rather to a drop in production. To solve this problem, the present study proposes to define a latex harvesting technology (or technologies) for the moderate metabolism clone class that will allow the improvement of plantation yield and the increase of the economic life of the trees. To achieve this, the GT 1, RRIC 100 and BPM 24 clones of the moderate metabolism class were used as plant material. The results showed that the reduction in tapping frequency had no negative effect on the vegetative state of the trees. This reduction was compensated by a high number of annual stimulations, which resulted in high dry rubber production. Analysis of dry rubber production, radial rubber growth and tapping panel dryness rate indicates that the moderate metabolic class clones performed better with the latex harvesting technologies $S / 2$ d3 6d/7 ET2.5\% Pa1(1) 6/y; S/2 d4 6d/7 ET2.5\% Pa1(1) 6/y and $S / 2$ d5 6d/7 ET2.5\% Pa1(1) 1.

Keywords: Côte d'Ivoire, Hevea Brasiliensis, Latex harvesting technologies, moderate metabolism.

Published Online: December 12, 2021

ISSN: 2684-5199

DOI : $10.24018 /$ ejbio.2021.2.6.301

Moussa Diarrassouba*

Ecole Normale Supérieure d'Abidjan (ENS), Abidjan, Côte d'Ivoire.

(e-mail: diarrassouba.moussa@ensabj.ci)

Souleymane Sanogo

Université Félix-Houphouët-Boigny,

Abidjan, Côte d'Ivoire.

(e-mail: sanogosousa@yahoo.fr)

Brahima Camara

Université Félix-Houphouët-Boigny,

Abidjan, Côte d'Ivoire.

(e-mail: camara_ib@yahoo.fr)

N'guessan Samuel Obouayeba

Centre National de Recherche Agronomique

(CNRA), Station de Bimbresso, Côte d'Ivoire.

(e-mail: obouayeba12samuel@yahoo.com)

*Corresponding Author

\section{INTRODUCTION}

Hevea brasiliensis Muell. Arg. (Euphorbiaceae) is the most important source of natural rubber production in the world (Rajagopal et al., 2003). This plant is appreciated for its rubber quality and productivity (Sekhar, 1989). The elasticity of its rubber makes it a popular material in the field of medicine (gloves, condoms, etc.) and in the tyre industry. In addition, there is a difference in the biological activity of the laticifers of the clones making up the metabolic classes (Eschbach et al., 1984; Jacob et al., 1985; Prevot et al., 1986; Commere et al., 1988). There are three metabolic classes. They include the classes of clones with rapid or active metabolism, clones with intermediate or moderate metabolism and clones with low or slow metabolism (Gohet et al., 1991; Jacob et al., 1995; Gohet et al., 1996). Clones in the moderate metabolism class have an easy flow of latex. In this class, there are clones that give average production without any stimulation. Strong stimulation is detrimental to the survival of this class of rubber trees. The response to hormonal stimulation of rubber production is poor.

However, in a global context of high cost and/or scarcity of tapping labour, as well as high input costs, the new general approach is, among others, to reduce tapping intensity with an appropriate policy of hormonal stimulation of rubber production (Rajagopal et al., 2003; Vijayakumar et al., 2003; Thomas et al., 2003; Soumahin et al., 2009; Soumahin et al., 2010). In order to maintain or even increase the productivity of the rubber tree in the long term while dealing with the availability and cost of labor on the one hand, and to meet the ever-increasing demand for natural rubber on the other, a great deal of significant work has been carried out in the field of the physiology of the plant and latex (Jacob et al., 1985). Previous studies, Obouayeba et al. (2009a); Coulibaly et al. (2011) and Sahabane et al. (2011) have certainly suggested latex harvesting technologies for the rational and efficient management of certain clones. However, very few studies exist in Côte d'Ivoire and in rubber-growing Africa aimed at developing latex harvesting technologies by metabolic class that are adapted to their requirements as well as to the socio-economic conditions of the country. The present study aims to improve the 
exploitation of clones of the moderate metabolic class by selecting latex harvesting technologies that are best adapted to them.

\section{MATERIALS AND METHODS}

\section{A. Plant Material}

The plant material consisted of three clones of Hevea basiliensis. These are the clones GT 1, RRIC 100, BPM 24.

1. Clones of the moderate or medium metabolism class (GT 1, RRIC 100 and BPM 24).

\section{1) GT 1 clone}

This clone originated from Gondang Tapen, an island in Java, Indonesia. It is the most popular clone in Côte d'Ivoire because of its rusticity and resistance to dry notch (Chapuset, 2001). It has physiological and biochemical characteristics suitable for production (Anonymous, 1993). GT 1 is the standard clone in Côte d'Ivoire.

\section{2) Clone RRIC 100}

It originates from Malaysia and was first planted in the LSCF (Large Scale Clone Field) in 1980. It is easily distinguished by the large size of its leaves and seeds. It has early defoliation and a limited physiological profile due to low content of thiol compounds. It is as vigorous as the GT 1 clone (Table I). Its production in grams per tree and per tapping is average. It has the advantage of being resistant to Colletotrichum and Corynespora infections (Chapuset, 2001).

\section{3) Clone BPM 24}

This is a cross between GT 1 and AVROS 1734. First planted in Côte d'Ivoire in 1990, it has a good production at opening (first tapping). It has a thin bark and produces abundant light-coloured, round seeds. Clone BPM 24 has a frail and heterogeneous appearance. It has a round crown and abundant light branches (Chapuset, 2001).

\section{4) Clone BPM 24}

This is a cross between GT 1 and AVROS 1734. First planted in Côte d'Ivoire in 1990, it has a good production at opening. It has a thin bark and produces abundant lightcolored, round seeds. Clone BPM 24 has a weak and heterogeneous aspect. It has a round crown and numerous light branches (Chapuset, 2001).

\section{B. Methods}

\section{1) Study site}

The study site is located in southwestern Côte d'Ivoire, coordinates $4^{\circ} 45^{\prime} \mathrm{N}, 6^{\circ} 38^{\prime} \mathrm{W}$. This area is covered by rainforest. The soils are ferralitic, highly desatured and characterized by an abundance of exchangeable bases. In this region, soils are sandy clay (texture) with gravely layers (Brou, 2005; Perraud, 1971; Roose \& Cherroux, 1966). The annual average rainfall is $1800-2000 \mathrm{~mm}$ with mean annual temperatures ranging between 28.5 and $29^{\circ} \mathrm{C}$ (Eldin, 1971).

\section{2) Experimental design}

The design used in all our experiments is a Fisher block design with 6 treatments and 4 replications with 100 trees per plot. Each trial covers an average area of 4.7 ha.

\section{3) Treatments}

For all clones, five tapping frequencies were used (d2, d3, $\mathrm{d} 4, \mathrm{~d} 5$ and d6). Tapping was done in a half-spiral downward direction. The hormonal stimulation system for production was defined according to the moderate metabolism of the clones. The ratings used were the international ratings for latex harvesting technologies (Lukman, 1983; Vijayakumar et al., 2009). The treatments or latex harvesting technologies applied were defined in Table I.

TABLE I: TREATMENTS APPLIED to ClONES ACCORDING TO MODERATE

\begin{tabular}{cccccc}
\multicolumn{5}{c}{ METABOLISM CLASS } \\
\hline $\mathrm{N}^{\circ}$ & $\begin{array}{c}\text { Notch } \\
\text { length }\end{array}$ & $\begin{array}{c}\text { Tapping } \\
\text { Frequencies }\end{array}$ & $\begin{array}{c}\text { Ethephon } \\
\text { concentration } \\
(\%)\end{array}$ & $\begin{array}{c}\text { Application } \\
\text { mode }\end{array}$ & $\begin{array}{c}\text { Tapping } \\
\text { Frequencies }\end{array}$ \\
\hline 1 & $\mathrm{~S} / 2$ & $\mathrm{~d} 26 \mathrm{~d} / 7$ & & & nil \\
2 & $\mathrm{~S} / 2$ & $\mathrm{~d} 36 \mathrm{~d} / 7$ & ET 2,5 & $\mathrm{~Pa} 1(1)(\mathrm{T})$ & $\begin{array}{c}\text { stimulation } \\
6 / \mathrm{y}\end{array}$ \\
3 & $\mathrm{~S} / 2$ & $\mathrm{~d} 46 \mathrm{~d} / 7$ & ET 2,5 & $\mathrm{~Pa} 1(1)$ & $6 / \mathrm{y}$ \\
4 & $\mathrm{~S} / 2$ & $\mathrm{~d} 46 \mathrm{~d} / 7$ & ET 2,5 & $\mathrm{Pa} 1(1)$ & $10 / \mathrm{y}$ \\
5 & $\mathrm{~S} / 2$ & $\mathrm{~d} 56 \mathrm{~d} / 7$ & ET 2,5 & $\mathrm{Pa} 1(1)$ & $10 / \mathrm{y}$ \\
6 & $\mathrm{~S} / 2$ & $\mathrm{~d} 66 \mathrm{~d} / 7$ & ET 2,5 & $\mathrm{Pa} 1(1)$ & $12 / \mathrm{y}$ \\
\hline
\end{tabular}

$\mathrm{S} / 2 \mathrm{~d} 2$ 6d/7: Downward half-spiral bleeding every other day, six working days a week.

S/2 d3 6d/7: Downward half-spiral bleeding every third day, six working days a week.

S/2 d4 6d/7: Downward half-spiral bleeding every fourth day, six working days a week.

S/2 d5 6d/7: Downward half-spiral bleeding every five days, six working days a week.

S/2 d6 6d/7: Downward half-spiral bleeding every six days, six working days a week.

ET 2.5\%: Stimulation with $2.5 \%$ concentrated ethephon.

Pa1(1): Stimulation carried out on the bleeding panel with $1 \mathrm{~g}$ of stimulant on a $1 \mathrm{~cm}$ wide strip $1 \mathrm{~cm}$ wide strip.

4/y: 4 stimulations per year.

6/y: 6 stimulations per year. 8/y: 8 stimulations per year.

10/y: 10 stimulations per year.

12/y: 12 stimulations per year.

15/y: 15 stimulations per year.

18/y: 18 stimulations per year.

nil stimulation: unstimulated treatment.

\section{Measured Parameters}

\section{1) Measurement of dry rubber production}

During the experimental period from the opening or tapping to 9 years of latex harvesting, the production was recorded per treatment, per clone. This activity consisted of collecting the rubber production contained in the cups and weighing it (fresh weight: Pf). This is done every 4 weeks. A sample of each treatment was then creped (creped weight: $\mathrm{CW}$ ) and oven dried at $80{ }^{\circ} \mathrm{C}$ for 24 hours and reweighed (dry weight: DW). Creping consisted of crushing the coagulum between two metal rollers rotating in opposite directions. This flattened coagulum is much easier to dry. This process removes a large part of the water contained in the coagulum. The rubber trees with total dry notch, uprooted or broken, were eliminated. For the conversion of the fresh weight to dry weight of each treatment, the transformation coefficient (TC) was first determined according to the following formula:

$$
\mathrm{TC}=\mathrm{Pw} \times \mathrm{Fw}-1 \times 100
$$

where

TC - Transformation coefficient; 
$\mathrm{Pw}$ - Crepe weight;

Fw - Fresh weight.

In a second step, the dry weight (Ps) was calculated according to the following formula:

Dry rubber production was expressed in kilograms per hectare per year $\left(\mathrm{kg} \cdot \mathrm{ha}^{-1} \cdot \mathrm{yr}^{-1}\right)$, gram per tree per year (g. $\left.\mathrm{t}^{-1} \cdot \mathrm{yr} \mathrm{r}^{-1}\right)$ and gram per tree per tapping $\left(\mathrm{g} . \mathrm{t}^{-1} \cdot \mathrm{t}^{-1}\right)$. The production in $\mathrm{kg} \cdot \mathrm{ha}^{-1} \cdot \mathrm{yr}^{-1}$ expresses the annual production of dry rubber per hectare of rubber trees. Since for each hectare the number of trees was not the same, the production in g. $\mathrm{t}^{-1} \cdot \mathrm{yr}^{-1}$ remedies the influence of the area on the production.

\section{2) Evaluation of the tapping panel dryness rate}

This estimation is done visually (Van De Sype, 1984). The observer follows the tappers and gives each bled tree a score ranging from 0 to 6 on a defined scale. This scale is proportional to the state of progress of the tapping panel dryness (TPD) and is described as follows:

0 : the notch is healthy and the latex flows normally along its entire length;

1 : notch is dry for 1 to $20 \%$ of its total length;

2: Notch is dry for $21-40 \%$ of its total length (less than half of the notch is dry);

3: $41-60 \%$ of the total length of the notch is dry (at least half of the notch is dry);

4: Notch dry for 61 to $80 \%$ of its total length (more than $60 \%$ of the notch is dry);

5: $81-100 \%$ of the notch is dry (almost the entire notch is dry);

6: after tapping, there is no latex flow. The entire length of the notch is dry.

DN: tree whose tapping is stopped because of the dry notch.

At the end of this work, the affected and unaffected trees were counted and then classified according to the scale defined above according to the following formula:

$$
\mathrm{N}=0.1 \mathrm{n} 1+0.3 \mathrm{n} 2+0.5 \mathrm{n} 3+0.7 \mathrm{n} 4+0.9 \mathrm{n} 5+\mathrm{n} 6+\mathrm{ES}
$$

where

$\mathrm{N}$ - total number of trees;

$\mathrm{n} 0$ - healthy trees of class 0 ;

$\mathrm{n} 1$ - diseased trees of class 1 ;

$\mathrm{n} 2$ - diseased trees of class 2 ;

$\mathrm{n} 3$ - diseased trees of class 3 ;

$\mathrm{n} 4$ - diseased trees of class 4 ;

n5 - diseased trees of class 5 ;

n6 - diseased trees of class 6 .

The coefficients assigned to each class are the average percentage of diseased notches in the given class.

The total diseased notch length rate was calculated by the following formula:

$$
\mathrm{LDN}=(\mathrm{N}+\mathrm{nDT}) /(\mathrm{n} 0+\mathrm{n} 1+\mathrm{n} 2+\mathrm{n} 3+\mathrm{n} 4+\mathrm{n} 5+\mathrm{n} 6+\mathrm{DN})
$$

where

nDT - Number of dry trees;

LDN - Length of diseased notch.

$\%$ diseased trees $=100 \%-(\%$ dry trees $+\%$ healthy trees $)$

\section{3) Determination of tapping intensity}

The tapping intensities (SI) of the latex harvesting technologies were calculated according to the formula below. The $\mathrm{S} / 2 \mathrm{~d} 2 \mathrm{6d} / 7$ tapping system was used as a reference or standard system:

$$
\text { IT }(\%)=2 \times \text { LTN } \times \text { NTYx } / \text { NATi } \times 100
$$

where

IT - Intensity of tapping ;

LTN: Length of the tapping notch, which was $S / 2$ in our study, i.e., $1 / 2$;

NTYx - Number of tappings per year for a given treatment frequency;

NSAi - Number of annual tapping for the standard tapping frequency (d2).

\section{4) Vegetative growth}

Trees were selected on the basis of trunk circumference measured at a height of $1 \mathrm{~m}$ before tapping. During bleeding, circumferences were measured at $1.70 \mathrm{~m}$ from the ground. All measurements were made with a tape measure. Each year at the end of each physiological cycle, i.e., before the beginning of defoliation (which corresponds to the months of January and February), the circumference of the trunk of each selected tree was measured again at a height of $1.70 \mathrm{~m}$ from the ground. From year to year, broken, uprooted or dry-notched trees were removed from the base file. This allowed the circumferences of trees still tappable at the end of the trial to be determined.

\section{5) Statistical analysis}

XLSTAT-Pro 6.1.9 software was used for the analyses of variance of the data on dry rubber production, dry notch rate and tree circumferences. The Newman-Keuls test at the 5\% threshold was used to distinguish the different groups.

\section{RESULTS}

\section{A. Average Annual Dry Rubber Production of Clones}

\section{1) Clone GT 1}

Table II presents the average annual dry rubber production of clone GT 1 expressed in g.t $\mathrm{t}^{-1} \cdot \mathrm{t}^{-1} ; \mathrm{g} \cdot \mathrm{t}^{-1} \cdot \mathrm{yr} \mathrm{r}^{-1}$ and $\mathrm{kg} \cdot \mathrm{ha}^{-1} \cdot \mathrm{yr}^{-1}$ under different latex harvesting technologies or treatments in southwestern Côte d'Ivoire.

\section{1.) Dry rubber production in $g . t^{-1} \cdot t^{-1}$}

The rubber production of the d6-12/y latex harvesting technology (treatment 6) with a value of $70 \mathrm{~g} \cdot \mathrm{t}^{-1} \cdot \mathrm{t}^{-1}$ was the highest of all. The lowest production $\left(27\right.$ g.t $\left.\mathrm{t}^{-1} \cdot \mathrm{t}^{-1}\right)$ was obtained with the trees of pattern 2 . Treatments 3 (d4-6/y) and $4(\mathrm{~d} 4-10 / \mathrm{y})$, bled at the same frequency, had identical productions of $55 \mathrm{~g} . \mathrm{t}^{-1} \cdot \mathrm{t}^{-1}$. For the same tapping frequency, increasing the number of stimulations had no effect on dry rubber production per tree and per tapping. However, at the same stimulation level of $6 / y$ or $10 / y$, rubber production increased with the reduction of tapping intensity. In general, rubber yields increased with reduced tapping intensity (Table II).

1.2) Dry rubber production in $g . t^{-1} \cdot y r^{-1}$

The rubber production of the $\mathrm{d} 3-6 / \mathrm{y}$ pattern, which was 4418 g.t-1.yr-1, was higher than those of treatments 1 $\left(4024\right.$ g.t $\left.t^{-1} \cdot \mathrm{yr}^{-1}\right), 5\left(3984\right.$ g.t $\left.\mathrm{t}^{-1} \cdot \mathrm{yr}^{-1}\right)$ and 6 (3484 g.t-1.yr $\left.{ }^{-1}\right)$. 
This production was identical to those of treatments 3 (d4$6 / y)$ and 4 (d4-10/y), whose values were 4155 and $4131 \mathrm{~g} \cdot \mathrm{t}^{-1} \cdot \mathrm{yr}^{-1}$, respectively. The lowest production was obtained with pattern $6\left(3484\right.$ g.t $\left.t^{-1} \cdot \mathrm{yr}^{-1}\right)$. When the trees were bled at the same frequency $\mathrm{d} 4$ (treatments 3 and 4 ), the productions were of the same order of magnitude. For the same level of stimulation $6 / y$ or $10 / y$, rubber yields were identical (Table II).

\section{3) Dry rubber production in $\mathrm{kg} \cdot \mathrm{ha}^{-1} \cdot \mathrm{yr}^{-1}$}

The yield of $2115 \mathrm{~kg} \cdot \mathrm{ha}^{-1} \cdot \mathrm{yr}^{-1}$ of treatment 2 (d3-6/y) was higher than those of treatments 5 (d5-10/y) and 6 (d6-12/y) with values of $1918 \mathrm{~kg} \cdot \mathrm{ha}^{-1} \cdot \mathrm{yr}^{-1}$ and $1700 \mathrm{~kg} \cdot \mathrm{ha}^{-1} \cdot \mathrm{yr}^{-1}$ respectively. For the same tapping frequency d4, the yields of trees in treatments 3 and 4 were $2002 \mathrm{~kg} \cdot \mathrm{ha}^{-1} \cdot \mathrm{yr}^{-1}$ and $1989 \mathrm{~kg} \cdot \mathrm{ha}^{-1} \cdot \mathrm{yr}^{-1}$ respectively. Similarly, for the same stimulation regime $(6 / y$ or $10 / y)$, the yields of the rubber trees were identical for latex harvesting technologies 2 and 3 for the 6/y stimulation level and for patterns 4 and 5 for the 10/y stimulation regime. However, the high tapping intensity latex harvesting technologies ( 22 and $\mathrm{d} 3$ ) had the same yield regardless of the number of annual stimulations (Table II).

\section{2) Clone RRIC 100}

Table III presents the average annual dry rubber production of the RRIC 100 clone, expressed in $\mathrm{g} \cdot \mathrm{t}^{-1} \cdot \mathrm{t}^{-1}$; g.t $\mathrm{t}^{-1} \cdot \mathrm{yr}^{-1}$ and in $\mathrm{kg} \cdot \mathrm{ha}^{-1} \cdot \mathrm{yr}^{-1}$ according to different treatments in southwestern Côte d'Ivoire.

\section{1) Dry rubber production in $g . t^{-1} \cdot t^{-1}$}

Rubber production increased from 29 to $79 \mathrm{~g} \cdot \mathrm{t}^{-1} \cdot \mathrm{t}^{-1}$ with tapping intensity. Tapping every 6 days (treatment 6) showed a production of $79 \mathrm{~g} \cdot \mathrm{t}^{-1} \cdot \mathrm{t}^{-1}$ which was higher than the other treatments. Patterns 3 and 4 ; bled at the same frequency, had productions of 59 and 58 g.t $\mathrm{t}^{-1} \cdot \mathrm{t}^{-1}$ respectively. These values were equivalent. For the same level of stimulation $6 / y$ or $10 / y$, the productions increased with the reduction of the tapping frequency (Table III). For the 6/y stimulation regime, production increased from 46 to 59 g.t $\mathrm{t}^{-1} \cdot \mathrm{t}^{-1}$ for tapping frequencies ranging from $\mathrm{d} 3$ (treatment 2) to $\mathrm{d} 4$ (treatment 3 ). For the 10/y stimulation level, production increased from 58 to $65 \mathrm{~g} \cdot \mathrm{t}^{-1} \cdot \mathrm{t}^{-1}$ for tapping frequencies of $\mathrm{d} 4$ (pattern 4) and $\mathrm{d} 5$ (pattern 5) respectively.

\section{2) Dry rubber production in $g \cdot t^{-1} \cdot y r^{-1}$}

Trees tapped in $\mathrm{d} 2$ and not stimulated (treatment 1 ) with a production of 4411 g.t $\mathrm{t}^{-1} \cdot \mathrm{yr}^{-1}$ as well as those in treatments 2 (4559 g.t $\left.\mathrm{t}^{-1} \cdot \mathrm{yr}^{-1}\right) ; 3$ (4461 g.t $\mathrm{t}^{-1} \cdot \mathrm{yr}^{-1}$ ) and 4 (4370 g. $\mathrm{t}^{-1} \cdot \mathrm{yr}^{-1}$ ) gave identical productions. However, the highest production (4559 g.t $^{-1} \cdot \mathrm{yr}^{-1}$ ) was obtained with treatment 2 , and the lowest (3906 g.t-1.yr-1) with trees in treatment 6. Patterns 3 and 4 , bled at the same frequency, had productions of 4461 g. $\mathrm{t}^{-1} \cdot \mathrm{yr}^{-1}$ and $4370 \mathrm{~g} . \mathrm{t}^{-1} \cdot \mathrm{yr}^{-1}$ respectively, which were equivalent (Table III).

\section{3) Dry rubber production in $\mathrm{kg} \cdot \mathrm{ha}^{-1} \cdot \mathrm{yr}^{-1}$}

The yields of the trees in patterns $1\left(2000 \mathrm{~kg} \cdot \mathrm{ha}^{-1} \cdot \mathrm{yr}^{-1}\right), 2$ (2055 kg.ha- $\left.{ }^{-1} \cdot \mathrm{yr}^{-1}\right), 3\left(2003 \mathrm{~kg} \cdot \mathrm{ha}^{-1} \cdot \mathrm{yr}^{-1}\right), 4$ (1975 kg.ha $\left.{ }^{-1} \cdot \mathrm{yr}^{-1}\right)$ and 5 (1934 kg.ha $\left.{ }^{-1} \cdot \mathrm{yr}^{-1}\right)$, were equal to each other. However, these values were higher than that of the production of trees in treatment $6\left(1725 \mathrm{~kg} \cdot \mathrm{ha}^{-1} \cdot \mathrm{yr}^{-1}\right)$, which was the lowest. For the same level of stimulation (6/y or $10 / y$ ), yields were identical (Table III). At the same tapping frequency (d4), patterns 3 and 4 had identical yields, even though the stimulation regime was changed from $6 / y$ to $10 / y$.

\section{3) Clone BPM 24}

Table IV presents the average annual dry rubber production of the BPM 24 clone expressed in g.t $^{-1} \cdot \mathrm{t}^{-1}$; g. $\mathrm{t}^{-1} \cdot \mathrm{yr}^{-1}$ and in $\mathrm{kg} \cdot \mathrm{ha}^{-1} \cdot \mathrm{yr}^{-1}$ according to different treatments in the southwest of Côte d'Ivoire.

\section{1) Dry rubber production in $g . t^{-1} \cdot t^{-1}$}

Trees in pattern 6 had a higher production $\left(82 \mathrm{~g} \cdot \mathrm{t}^{-1} \cdot \mathrm{t}^{-1}\right)$ than the other treatments. The lowest production, $32 \mathrm{~g} \cdot \mathrm{t}^{-1} \cdot \mathrm{t}^{-1}$ was obtained with pattern 1 . Rubber trees in treatments 3 and 4, which were bled in d4 and stimulated in 6/y and 10/y, respectively, produced 63 and 65 g.t $\mathrm{t}^{-1} \cdot \mathrm{t}^{-1}$, which were identical. Production increased from 32 to 82 g.t $\mathrm{t}^{-1} \cdot \mathrm{t}^{-1}$ with reduced latex harvesting intensity. For trees stimulated at the same $6 / y$ or $10 / y$ level; production increased with reduction in bleeding frequency (Table IV). For the 6/y stimulation regime, production was greater (i.e., 63 g.t. $\mathrm{t}^{-1} \cdot \mathrm{t}^{-1}$ ) in trees in treatment 3 than in those in treatment $2\left(50 \mathrm{~g} \cdot \mathrm{t}^{-1} \cdot \mathrm{t}^{-1}\right)$. For stimulation level $10 / y$, production was greater with latex harvesting technology $5\left(74 \mathrm{~g} \cdot \mathrm{t}^{-1} \cdot \mathrm{t}^{-1}\right)$ than with trees in pattern $4\left(65 \mathrm{~g} \cdot \mathrm{t}^{-1} \cdot \mathrm{t}^{-1}\right)$.

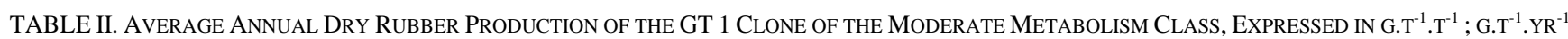
AND IN KG.HA ${ }^{-1}$ YR $^{-1}$ AS A FUNCTION OF TREATMENTS IN THE SOUTH-WEST OF CÔTE D'IVOIRE AFTER NINE YEARS OF EXPERIMENTATION

\begin{tabular}{|c|c|c|c|c|c|}
\hline \multirow{2}{*}{ Treatments or latex harvesting technologies } & \multirow{2}{*}{$\begin{array}{c}\text { Tapping intensity } \\
(\%)\end{array}$} & \multirow{2}{*}{$\begin{array}{c}\text { Number of tappings } \\
\text { per year }\end{array}$} & \multicolumn{3}{|c|}{ Rubber yield } \\
\hline & & & g.t ${ }^{-1} \cdot \mathrm{t}^{-1}$ & g. $\mathrm{t}^{-1} \cdot \mathrm{yr}^{-1}$ & kg.ha ${ }^{-1} \cdot \mathrm{yr}^{-1}$ \\
\hline 1. S/2 d2 nil stimulation (témoin) & 100 & 156 & $27 \mathrm{e}$ & $4024 \mathrm{~b}$ & 1974 ab \\
\hline 2. $\mathrm{S} / 2 \mathrm{~d} 36 \mathrm{~d} / 7 \mathrm{ET} 2.5 \% \mathrm{~Pa} 1(1) 6 / \mathrm{y}$ & 67 & 104 & $44 \mathrm{~d}$ & 4418 a & $2115 \mathrm{a}$ \\
\hline 3. $\mathrm{S} / 2 \mathrm{~d} 46 \mathrm{~d} / 7 \mathrm{ET} 2.5 \% \mathrm{~Pa} 1(1) 6 / \mathrm{y}$ & 50 & 78 & $55 \mathrm{c}$ & $4155 \mathrm{ab}$ & $2002 \mathrm{ab}$ \\
\hline 4. $\mathrm{S} / 2 \mathrm{~d} 46 \mathrm{~d} / 7 \mathrm{ET} 2.5 \% \mathrm{~Pa} 1(1) 10 / \mathrm{y}$ & 50 & 78 & $55 \mathrm{c}$ & $4131 \mathrm{ab}$ & $1989 \mathrm{ab}$ \\
\hline 5. S/2 d5 6d/7 ET2.5\% Pa1(1) 10/y & 40 & 65 & $63 \mathrm{~b}$ & $3984 \mathrm{~b}$ & $1918 \mathrm{~b}$ \\
\hline 6. S/2 d6 6d/7 ET2.5\% Pa1(1) $12 / y$ & 33 & 52 & $70 \mathrm{a}$ & $3484 \mathrm{c}$ & $1700 \mathrm{c}$ \\
\hline
\end{tabular}

$\mathrm{a}, \mathrm{b}, \mathrm{c}, \mathrm{d}, \mathrm{e}, \mathrm{f}$ : production means with the same letter are not significantly different (Newman-Keuls test at $5 \%$ ).

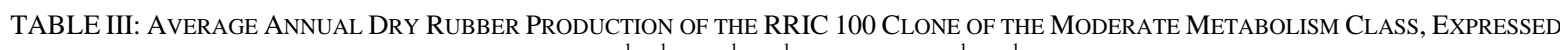

\begin{tabular}{|c|c|c|c|c|c|}
\hline \multirow[b]{2}{*}{ Treatments or latex harvesting technologies } & \multirow{2}{*}{$\begin{array}{c}\text { Tapping } \\
\text { Intensity }(\%)\end{array}$} & \multirow{2}{*}{$\begin{array}{c}\text { Number of } \\
\text { tappings per } \\
\text { year }\end{array}$} & \multicolumn{3}{|c|}{ Rubber yield } \\
\hline & & & g.t. $\mathrm{t}^{-1} \cdot \mathrm{t}^{-1}$ & g.t $t^{1} \cdot \mathrm{yr}^{-1}$ & $\mathrm{~kg} \cdot \mathrm{ha}^{-1} \cdot \mathrm{yr}^{-1}$ \\
\hline 1. S/2 d2 nil stimulation (témoin) & 100 & 156 & 29 e & 4411 ab & 2000 a \\
\hline 2. $\mathrm{S} / 2 \mathrm{~d} 36 \mathrm{~d} / 7 \mathrm{ET} 2.5 \% \mathrm{~Pa} 1(1) 6 / \mathrm{y}$ & 67 & 104 & $46 \mathrm{~d}$ & 4559 a & $2055 \mathrm{a}$ \\
\hline 3. $\mathrm{S} / 2 \mathrm{~d} 46 \mathrm{~d} / 7 \mathrm{ET} 2.5 \% \mathrm{~Pa} 1(1) 6 / \mathrm{y}$ & 50 & 78 & $59 \mathrm{c}$ & $4461 \mathrm{ab}$ & 2003 a \\
\hline 4. $\mathrm{S} / 2 \mathrm{~d} 46 \mathrm{~d} / 7 \mathrm{ET} 2.5 \% \mathrm{~Pa} 1$ (1) 10/y & 50 & 78 & $58 \mathrm{c}$ & $4370 \mathrm{ab}$ & $1975 \mathrm{a}$ \\
\hline 5. S/2 d5 6d/7 ET2.5\% Pa1(1) 10/y & 40 & 65 & $65 \mathrm{~b}$ & $4128 \mathrm{bc}$ & $1934 \mathrm{a}$ \\
\hline 6. S/2 d6 6d/7 ET2.5\% Pa1(1) 12/y & 33 & 52 & $79 \mathrm{a}$ & $3906 \mathrm{c}$ & $1725 \mathrm{~b}$ \\
\hline
\end{tabular}

a, b, c, d, e, f: production means with the same letter are not significantly different (Newman-Keuls test at 5\%). 


\section{2) Dry rubber production in $g . t^{-1} \cdot y r^{-1}$}

The productions of treatments 1 (4858 g.t $\left.\mathrm{t}^{-1} \cdot \mathrm{yr}^{-1}\right), 2$ (5039 g.t $\left.\mathrm{t}^{-1} \cdot \mathrm{yr} \mathrm{r}^{-1}\right) ; 3$ (4782 g.t $\left.\mathrm{t}^{-1} \cdot \mathrm{yr}^{-1}\right), 4$ (4923 g.t. $\left.\mathrm{t}^{-1} \cdot \mathrm{yr}^{-1}\right)$ and 5 (4705 g.t $\left.\mathrm{t}^{-1} \cdot \mathrm{yr}^{-1}\right)$ were identical. These values were higher than that of pattern $6\left(4137 \mathrm{~g} \cdot \mathrm{a}^{-1} \cdot \mathrm{yr}^{-1}\right)$. At the same tapping intensity (d4), the productions of patterns 3 (4782 g.t $\mathrm{t}^{-1} \cdot \mathrm{yr}^{-1}$ ) and 4 (4923 g.t t $\left.^{-1} \mathrm{yr}^{-1}\right)$ were identical even though the number of annual stimulations was increased from 6 to $10 / y$. Similarly, at the same stimulation regime (6/y or $10 / y)$, production remained identical even though the tapping frequencies were reduced from $\mathrm{d} 3$ to $\mathrm{d} 4$ or from $\mathrm{d} 4$ to $\mathrm{d} 5$ (Table IV).

\section{3) Dry rubber production in $\mathrm{kg} \cdot \mathrm{ha}^{-1} \cdot \mathrm{yr}^{-1}$}

The yield of trees in treatments 1 (2191 kg.ha-1.yr-1), 2 (2262 kg.ha- $\left.\cdot \mathrm{yr}^{-1}\right) ; 3$ (2108 kg.ha $\left.{ }^{-1} \cdot \mathrm{yr}^{-1}\right), 4$ (2231 kg.ha- $\left.{ }^{-1} \cdot \mathrm{yr}^{-1}\right)$ and $5\left(2084 \mathrm{~kg} \cdot \mathrm{ha}^{-1} \cdot \mathrm{yr}^{-1}\right)$ were identical to each other. However, these yields were higher than that of pattern 6 (d6$12 / \mathrm{y}$ ), which was $1861 \mathrm{~kg} \cdot \mathrm{ha}^{-1} \cdot \mathrm{y}^{-1}$. At equal tapping intensity (d4), yields were equal even though the number of annual stimulations was increased from 6 to 10/y. Similarly, at the same level of stimulation (6/y or 10/y) yields were equivalent (Table IV).Average production of the three clones GT 1, RRIC 100 and BPM 24

Table $\mathrm{V}$ shows the average annual dry rubber production of the GT 1, RRIC 100 and BPM 24 clones under different treatments in southwestern Côte d'Ivoire.

\section{1) Dry rubber production in $g . t^{-1} \cdot t^{-1}$}

Trees in treatment $6(\mathrm{~d} 6-10 / \mathrm{y})$ produced $77 \mathrm{~g} \cdot \mathrm{t}^{-1} \cdot \mathrm{t}^{-1}$ which was higher than those in treatments $1\left(29 \mathrm{~g} \cdot \mathrm{t}^{-1} \cdot \mathrm{t}^{-1}\right) ; 2$ (47 29

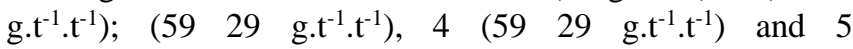
(67 29 g.t $\mathrm{t}^{-1} \cdot \mathrm{t}^{-1}$ ). The productions of rubber trees tapped at the same frequency $\mathrm{d} 4$, treatments $3(\mathrm{~d} 4-6 / \mathrm{y})$ and 4 (d4-10/y) were identical $\left(59 \mathrm{~g} \cdot \mathrm{t}^{-1} \cdot \mathrm{t}^{-1}\right)$. For trees stimulated at the same level, 6/y, productions were higher with treatment 3 (59 29 g. $\left.\mathrm{a}^{-1} \cdot \mathrm{t}^{-1}\right)$ than with treatment $2\left(4729\right.$ g.t $\left.\mathrm{t}^{-1} \cdot \mathrm{t}^{-1}\right)$. For the $10 / y$ stimulation regime, productions were higher (Table V) with rubber trees in treatment $5\left(6729\right.$ g.t. $\left.\mathrm{t}^{-1} . \mathrm{t}^{-1}\right)$ than with those in pattern 4 (59 29 g.t $\left.\mathrm{t}^{-1} \cdot \mathrm{t}^{-1}\right)$.

\section{2) Dry rubber production in $g \cdot t^{-1} \cdot y r^{-1}$}

The results showed that the production of treatment 2 (4677 g.t $\mathrm{t}^{-1} \cdot \mathrm{yr}^{-1}$ ) was higher than those of patterns 1 (4439 g.t $\left.\mathrm{t}^{-1} \cdot \mathrm{yr}^{-1}\right), 3$ (4472 g.t $\left.\mathrm{t}^{-1} \cdot \mathrm{yr}^{-1}\right), 4$ (4481 g.t $\left.\mathrm{t}^{-1} \cdot \mathrm{yr}^{-1}\right), 5$ (4278 g.t $\left.\mathrm{t}^{-1} \cdot \mathrm{yr}^{-1}\right)$ and $6\left(3849\right.$ g.t $\left.\mathrm{t}^{-1} \cdot \mathrm{yr}^{-1}\right)$. The production of $\mathrm{d} 2$ bleached and unstimulated trees in treatment 1 (467 g.t $\left.\mathrm{t}^{-1} \cdot \mathrm{yr}^{-1}\right)$ was equal to that of treatments 3 (d4-6/y) (4472 g.t $\left.\mathrm{t}^{-1} \cdot \mathrm{yr}^{-1}\right), 4(\mathrm{~d} 4-10 / \mathrm{y})\left(4481 \mathrm{~g} \cdot \mathrm{t}^{-1} \cdot \mathrm{yr}^{-1}\right)$ and 5 (d5-10/y) (4278 g.t $\left.\mathrm{t}^{-1} \cdot \mathrm{yr}^{-1}\right)$. For trees tapped at the same frequency d4, the productions of trees in treatments 3 (4472 g.t $\left.\mathrm{t}^{-1} \cdot \mathrm{yr}^{-1}\right)$ and 4 (4481 g.t $\left.\mathrm{t}^{-1} \cdot \mathrm{yr}^{-1}\right)$ were identical (Table V).

\section{3) Dry rubber production in $\mathrm{kg}^{\mathrm{h}} \mathrm{ha}^{-1} \cdot \mathrm{yr}^{-1}$}

The yields of the $\mathrm{d} 2$-spiked and unstimulated trees in treatment 1 (2057 kg.ha $\left.{ }^{-1} \cdot \mathrm{yr}^{-1}\right)$ and of the d4-spiked and 10times-stimulated trees in treatment $4\left(2066 \mathrm{~kg} \cdot \mathrm{ha}^{-1} \cdot \mathrm{yr}^{-1}\right)$ were identical to those of the $\mathrm{d} 3$-spiked and 6-times-stimulated rubber trees in treatment $2\left(2145 \mathrm{~kg} \cdot \mathrm{ha}^{-1} \cdot \mathrm{yr}^{-1}\right)$ Treatments 3 (2038 kg.ha- $\left.{ }^{-1} \cdot \mathrm{yr}^{-1}\right)$ and $5\left(1980 \mathrm{~kg} \cdot \mathrm{ha}^{-1} \cdot \mathrm{yr}^{-1}\right)$, whose trees were stimulated 6 and 10 times per year respectively and bled at frequencies d4 and d5, had identical productions. For rubber trees tapped at the same frequency $\mathrm{d} 4$, the yields of latex harvesting technologies $3\left(2038 \mathrm{~kg} \cdot \mathrm{ha}^{-1} \cdot \mathrm{yr}^{-1}\right)$ and 4 (2066 kg.ha- ${ }^{-1} \mathrm{yr}^{-1}$ ) were equivalent (Table V).

\section{B. Radial Vegetative Trunk Growth of Clones 1) Clone GT 1}

Fig. 1 shows the effect of the six treatments on the radial vegetative growth of trees of Hevea brasiliensis clone GT 1. The results indicated that for all treatments there was no difference in tree circumference. However, for rubber trees that were tapped at the same intensity of treatments 3 $(66.9 \mathrm{~cm})$ and $4(66.1 \mathrm{~cm})$, radial vegetative growth was significantly favoured by the lower stimulation level (pattern 3: d4-6/y). For the same stimulation regime (10/y), the trunk circumference of trees undergoing treatment 5 (d5-10/y), with a value equal to $67.1 \mathrm{~cm}$, was slightly greater than that of trees under treatment 4 (d4-10/y).

TABLE IV: AVERAGE ANNUAL Dry RubBER PRODUCTION OF THE BPM 24 CLONE OF THE MODERATE METABOLISM ClASS EXPRESSED IN G.T ${ }^{-1}$. $^{-1}$; G.T $^{-}$ ${ }^{1}$.YR $^{-1}$ AND IN KG.HA ${ }^{-1}$.YR ${ }^{-1}$ ACCORDING TO THE TREATMENTS IN THE SOUTH-WEST OF CÔTE D'IVOIRE AFTER NINE YEARS OF EXPERIMENTATION

\begin{tabular}{|c|c|c|c|c|c|}
\hline \multirow{2}{*}{ Treatments or latex harvesting technologies } & \multirow{2}{*}{$\begin{array}{c}\text { Tapping } \\
\text { Intensity }(\%)\end{array}$} & \multirow{2}{*}{$\begin{array}{c}\text { Number of } \\
\text { tappings per year }\end{array}$} & \multicolumn{3}{|c|}{ Rubber yield } \\
\hline & & & g.t $\mathrm{t}^{-1} \cdot \mathrm{t}^{-1}$ & g.t. ${ }^{-1} \cdot \mathrm{yr}^{-1}$ & $\mathrm{~kg} \cdot \mathrm{ha}^{-1} \cdot \mathrm{yr}^{-1}$ \\
\hline 1. S/2 d2 nil stimulation (témoin) & 100 & 156 & 32 e & 4858 a & 2191 a \\
\hline 2. $\mathrm{S} / 2 \mathrm{~d} 3 \mathrm{6d} / 7 \mathrm{ET} 2.5 \% \mathrm{~Pa} 1(1) 6 / \mathrm{y}$ & 67 & 104 & $50 \mathrm{~d}$ & 5039 a & $2262 \mathrm{a}$ \\
\hline 3. $\mathrm{S} / 2 \mathrm{~d} 4 \mathrm{6d} / 7 \mathrm{ET} 2.5 \% \mathrm{~Pa} 1(1) 6 / \mathrm{y}$ & 50 & 78 & $63 \mathrm{c}$ & 4782 a & $2108 \mathrm{a}$ \\
\hline 4. S/2 d4 6d/7 ET2.5 \% Pa1(1) 10/y & 50 & 78 & $65 \mathrm{c}$ & 4923 a & $2231 \mathrm{a}$ \\
\hline 5. S/2 d5 6d/7 ET2.5 \% Pa1(1) 10/y & 40 & 65 & $74 \mathrm{~b}$ & 4705 a & $2084 \mathrm{a}$ \\
\hline 6. S/2 d6 6d/7 ET2.5\% Pa1(1) 12/y & 33 & 52 & $82 \mathrm{a}$ & $4137 \mathrm{~b}$ & $1861 \mathrm{~b}$ \\
\hline
\end{tabular}

a, b, c, d, e, f: production means with the same letter are not significantly different (Newman-Keuls test at 5\%).

TABle V. Average AnNual Dry RubBer Production of All GT 1, RRIC 100 ANd BPM 24 ClONES OF THE Moderate MEtabolism Class,

EXPRESSED IN G.A $\mathrm{A}^{-1} \cdot \mathrm{S}^{-1}$; G.A $\mathrm{A}^{-1}$. YR $\mathrm{R}^{-1}$ AND KG.HA ${ }^{-1}$. YR $\mathrm{R}^{-1}$ AS A FUNCTION OF TREATMENTS IN SOUTH-WESTERN CÔTE D'IVOIRE AFTER NINE YEARS OF EXPERIMENTATION

\begin{tabular}{|c|c|c|c|c|c|}
\hline \multirow{3}{*}{ Treatments or latex harvesting technologies } & & \multirow{2}{*}{\multicolumn{3}{|c|}{ Rubber yield }} \\
\hline & Tapping Intensity & Number of tapping & & & \\
\hline & $(\%)$ & per year & g.t. ${ }^{-1} \cdot \mathrm{t}^{-1}$ & g.t $\mathrm{t}^{-1} \cdot \mathrm{yr}^{-1}$ & kg.ha' ${ }^{-1} \cdot \mathrm{yr}^{-1}$ \\
\hline 1. S/2 d2 nil stimulation (témoin) & 100 & 156 & 29 e & $4439 \mathrm{~b}$ & 2057 ab \\
\hline 2. S/2 d3 6d/7 ET2.5\% Pa1(1) 6/y & 67 & 104 & $47 \mathrm{~d}$ & 4677 a & $2145 \mathrm{a}$ \\
\hline 4. $\mathrm{S} / 2 \mathrm{~d} 46 \mathrm{~d} / 7 \mathrm{ET} 2.5 \% \mathrm{~Pa} 1$ (1) $10 / \mathrm{y}$ & 50 & 78 & $59 \mathrm{c}$ & $4481 \mathrm{~b}$ & $2066 \mathrm{ab}$ \\
\hline 5. $\mathrm{S} / 2 \mathrm{~d} 56 \mathrm{~d} / 7 \mathrm{ET} 2.5 \% \mathrm{~Pa} 1(1) 10 / \mathrm{y}$ & 40 & 65 & $67 \mathrm{~b}$ & $4278 \mathrm{~b}$ & $1980 \mathrm{~b}$ \\
\hline 6. $\mathrm{S} / 2 \mathrm{~d} 66 \mathrm{~d} / 7 \mathrm{ET} 2.5 \% \mathrm{~Pa} 1(1) 12 / \mathrm{y}$ & 33 & 52 & $77 \mathrm{a}$ & $3849 \mathrm{c}$ & $1763 \mathrm{c}$ \\
\hline
\end{tabular}

a, b, c, d, e, f: production means with the same letter are not significantly different (Newman-Keuls test at 5\%). 


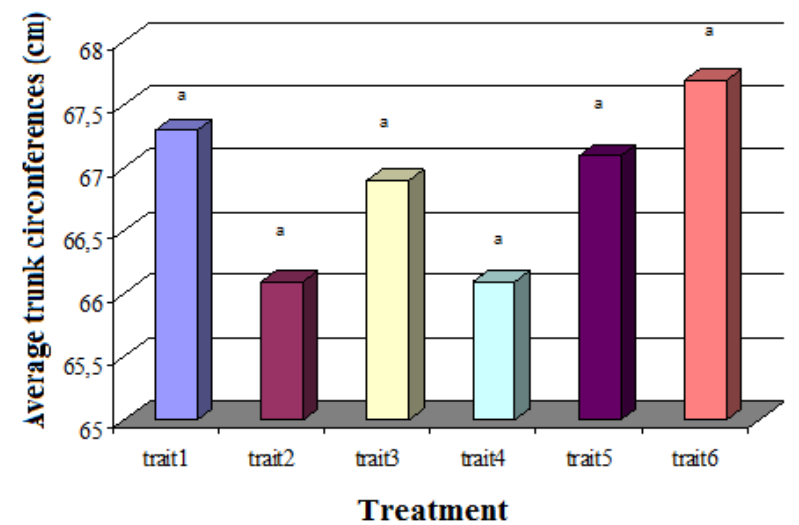

Fig. 1. Average trunk circumferences of trees according to treatments of the GT 1 clone after nine years of experimentation in southwestern Côte d'Ivoire.

Trait: treatment

Trait $1: \mathrm{S} / 2 \mathrm{~d} 2$ nil stimulation.

Trait $2: \mathrm{S} / 2 \mathrm{~d} 3$ 6d/7 ET2.5\% Pa1(1) 6/y.

Trait 3 : S/2 d4 6d/7 ET2.5\% Pa1(1) 6/y.

Trait 4: S/2 d4 6d/7 ET2.5\% Pa1(1) 10/y

Trait 5: S/2 d5 6d/7 ET2.5\% Pa1(1) 10/y.

Trait 6: S/2 d6 6d/7 ET2.5\% Pa1(1) 12/y.

a: Mean circumferences with the same letter are not significantly different (Scheffe's test at 5\%).

\section{2) Clone RRIC 100}

Fig. 2 shows the effect of the six treatments on the radial vegetative trunk growth of Hevea brasiliensis clone RRIC 100 trees. The circumference of the unstimulated and most frequently tapped rubber trees (treatment 1) with a value of $76.3 \mathrm{~cm}$, was higher than that of the other patterns. The circumference of trees in treatment $5(69.6 \mathrm{~cm})$ was lower than in treatments $1(76.3 \mathrm{~cm}), 3(72.8 \mathrm{~cm})$ and $6(73.6 \mathrm{~cm})$. The tree circumferences of patterns $2(70.8 \mathrm{~cm})$ and 4 $(70.8 \mathrm{~cm})$ were equal. For patterns $3(72.8 \mathrm{~cm})$ and 4 $(70.8 \mathrm{~cm})$, tapped at the same intensity $\mathrm{d} 4$, the circumferences of the rubber trees in these treatments were of the same order of magnitude. However, a slight gain in growth was obtained with the rubber trees in treatment 3 (d4-6/y). The radial vegetative growth of trees in treatments $4(70.8 \mathrm{~cm})$ and $5(69.5 \mathrm{~cm})$ stimulated at the same level $(10 / y)$, were equivalent. However, the girths of the trees in pattern 4 were significantly greater than in treatment 5 .

\section{3) Clone BPM 24}

Fig. 3 shows the effect of the six treatments on the radial vegetative growth of trees of the Hevea brasiliensis clone BPM 24. The circumferences of the trees in patterns $1(64.8$ $\mathrm{cm}), 3(63 \mathrm{~cm}), 4(62.6 \mathrm{~cm}), 5(63.4 \mathrm{~cm})$ and $6(64.4 \mathrm{~cm})$ were of the same order of magnitude. The trees in pattern 2 (d3-6/y) had the smallest circumferences of $61.9 \mathrm{~cm}$. These values were equivalent to those of the trees in treatment 4 $(\mathrm{d} 4-10 / \mathrm{y})$, which had a circumference of $62.6 \mathrm{~cm}$. For trees in treatments $2(61.9 \mathrm{~cm})$ and $3(63 \mathrm{~cm})$ stimulated at the same regime $(6 / y)$, circumferences were higher with pattern $3(63 \mathrm{~cm})$. However, for the same stimulation level of $10 / y$, the circumferences of the rubber trees in treatments 4 (62.6 $\mathrm{cm})$ and $5(63.4 \mathrm{~cm})$ were identical. When the rubber trees were tapped at the same frequency d 4 of patterns 3 and 4 , the tree circumferences were equivalent.

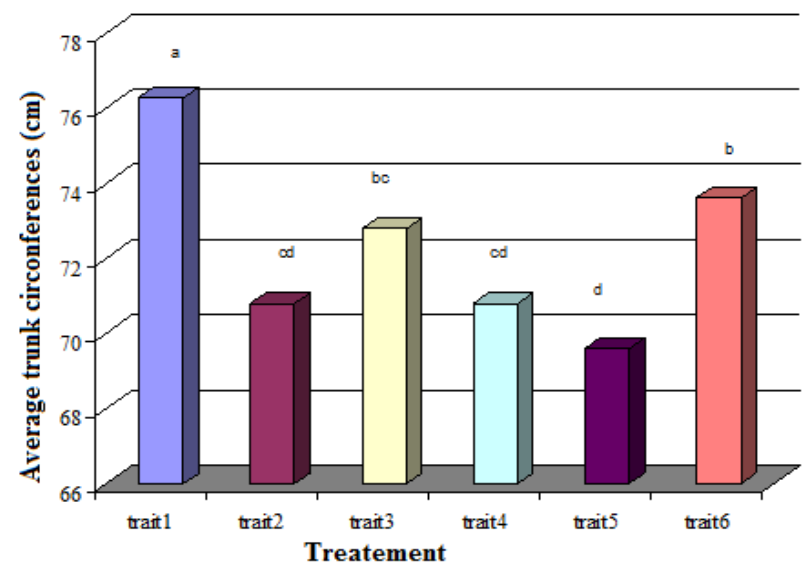

Fig. 2. Average trunk circumferences of trees according to treatments of the RRIC 100 clone after nine years of experimentation in southwestern Côte d'Ivoire.

Trait: treatment

Trait $1: \mathrm{S} / 2 \mathrm{~d} 2$ nil stimulation

Trait 2 : S/2 d3 6d/7 ET2.5\% Pa1(1) 6/y.

Trait 3 : S/2 d4 6d/7 ET2.5\% Pa1(1) 6/y.

Trait 4: S/2 d4 6d/7 ET2.5\% Pa1(1) 10/y.

Trait 5: S/2 d5 6d/7 ET2.5\% Pa1(1) 10/y.

Trait 6: S/2 d6 6d/7 ET2.5\% Pa1(1) 12/y.

a,b,c,d,e,f: production means with the same letter are not significantly different (Newman-Keuls test at 5\%).

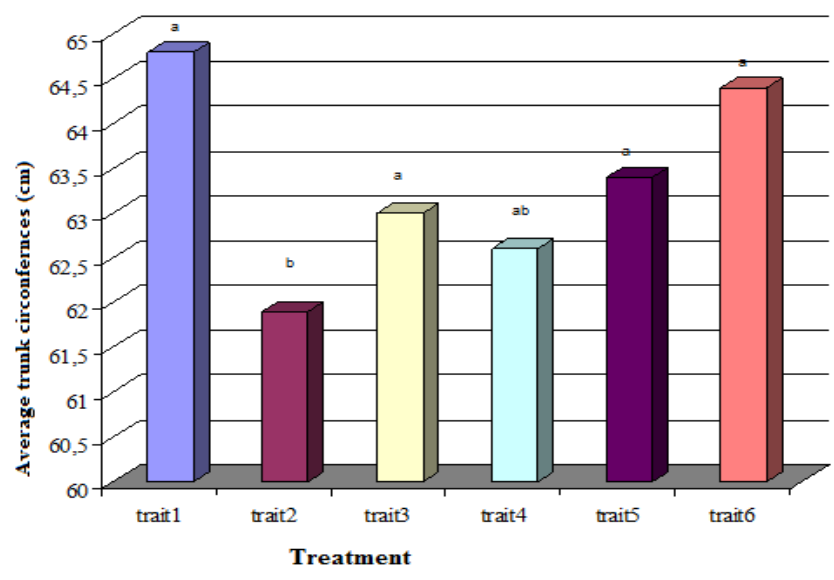

Fig. 3. Average trunk circumferences of trees according to treatments of the BPM 24 clone after nine years of experimentation in southwestern Côte d'Ivoire.

Trait: treatment.

Trait $1: \mathrm{S} / 2 \mathrm{~d} 2$ nil stimulation.

Trait $2: \mathrm{S} / 2 \mathrm{~d} 3$ 6d/7 ET2.5\% Pa1(1) 6/y.

Trait $3: \mathrm{S} / 2 \mathrm{~d} 4$ 6d/7 ET2.5\% Pa1(1) 6/y.

Trait 4: S/2 d4 6d/7 ET2.5\% Pa1(1) 10/y.

Trait 5: S/2 d5 6d/7 ET2.5 \% Pa1(1) 10/y.

Trait 6: S/2 d6 6d/7 ET2.5\% Pa1(1) 12/y.

a,b,c,d,e,f: production means with the same letter are not significantly different (Newman-Keuls test at 5\%).

\section{4) Average radial vegetative trunk growth of all GT 1 , RRIC 100 and BPM 24 clones}

Fig. 4 shows the effect of the six treatments on the mean vegetative growth of trees of Hevea brasiliensis clones GT 1, RRIC 100 and BPM 24. In general, treatments 1 (69.4 $\mathrm{cm}), 3(67.5 \mathrm{~cm})$ and $6(68.5 \mathrm{~cm})$ resulted in a similar amount of radial vegetative growth. The circumferences of latex harvesting technologies $2(66.2 \mathrm{~cm}), 4(66.5 \mathrm{~cm})$ and 5 $(66.7 \mathrm{~cm})$ were similar. At the same tapping frequency $(\mathrm{d} 4)$, the trees in patterns 3 and 4 had circumferences of $67.5 \mathrm{~cm}$ and $66.5 \mathrm{~cm}$ respectively, which were identical. Similarly, for rubber trees stimulated with the same regime (6/y for 
treatments 2 and 3 and 10/y for patterns 4 and 5), the circumferences were identical. The circumference value of trees in treatment $3(67.5 \mathrm{~cm})$ was identical to that of treatments $2(66.2 \mathrm{~cm}), 4(66.5 \mathrm{~cm})$ and $5(66.7 \mathrm{~cm})$.

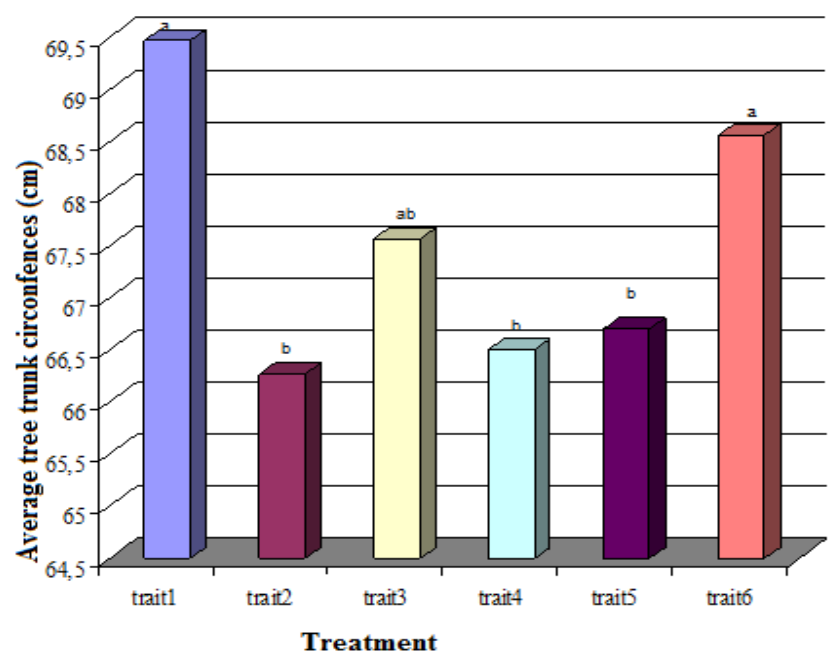

Fig. 4. Average tree trunk circumferences as a function of treatments for the GT 1, RRIC 100 and BPM 24 clones after nine years of experimentation in southwestern Côte d'Ivoire.

Trait: treatment.

Trait $1: \mathrm{S} / 2 \mathrm{~d} 2$ nil stimulation.

Trait 2 : S/2 d3 6d/7 ET2.5\% Pa1(1) 6/y.

Trait 3 : S/2 d4 6d/7 ET2.5\% Pa1(1) 6/y.

Trait 4: S/2 d4 6d/7 ET2.5 \% Pa1(1) 10/y.

Trait 5: S/2 d5 6d/7 ET2.5\% Pa1(1) 10/y.

Trait 6: S/2 d6 6d/7 ET2.5 \% Pa1(1) 12/y.

a,b,c,d,e,f: production means with the same letter are not significantly different (Newman-Keuls test at 5\%).

\section{Tapping Panel Dryness Rate of Clones \\ 1) Clone GT 1}

Fig. 5 shows the percentage tapping panel dryness(TPD) rate generated by each treatment applied to Hevea brasiliensis clone GT 1 trees in southwestern Côte d'Ivoire. The results showed that the highest percentage of TPD was recorded with trees in treatment $4(7.9 \%)$, and the lowest percentage with trees in pattern $2(2.9 \%)$. For trees tapped at the same frequency $\mathrm{d} 4$ in patterns 3 and 4 , increasing the number of annual stimulations resulted in a higher rate of TPD in pattern 4 trees $(7.9 \%)$ than in treatment $3(4.4 \%)$. In contrast, trees stimulated at the same 10/y level had a lower TPD rate with treatment $5(3.4 \%)$ than with treatment 4 (7.9\%).

\section{2) Clone RRIC 100}

Fig. 6 shows the percentage tapping panel dryness (TPD) rate generated by each treatment applied to trees of the Hevea brasiliensis clone RRIC 100 in southwestern Côte d'Ivoire. Unstimulated trees (treatment 1) gave the highest TPD rate with $10.6 \%$ while trees in patterns $5(\mathrm{~d} 5-10 / \mathrm{y})$ and 6 (d6-12/y) showed the lowest TPD percentage (3.9\%). Rubber trees in treatments 5 (d5-10/y) and 6 (d6-12/y), although tapped in different patterns, had equal TPD rates $(3.9 \%)$. For trees tapped at the same frequency (d4) as those in treatments $3(5.3 \%)$ and $4(7.5 \%)$, the TPD rate was highest in the latter case. However, when trees were stimulated at the same $6 / y$ level, relative to treatments 2 $(7.5 \%)$ and $3(5.3 \%)$, TPD rate was higher in the trees tapped at the higher frequency of treatment 2 (d3-6/y).

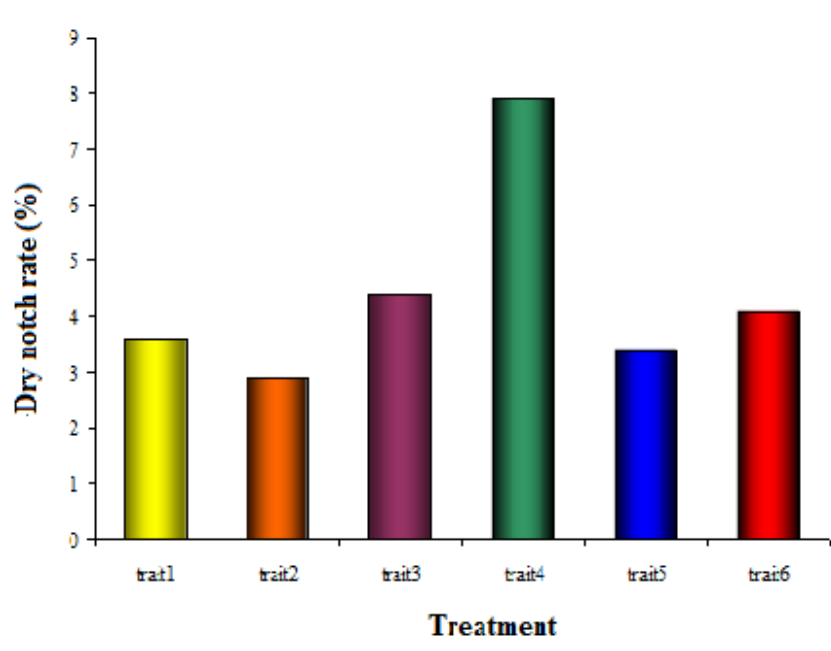

Fig. 5. Tapping panel dryness rate of Hevea brasiliensis clone GT 1, from the moderate metabolic class, in the south-western region of Côte d'Ivoire after nine years of latex harvesting in downward tapping on virgin bark of

Trait: treatment.

Trait $1: \mathrm{S} / 2 \mathrm{~d} 2$ nil stimulation.

Trait $2: \mathrm{S} / 2 \mathrm{~d} 36 \mathrm{~d} / 7 \mathrm{ET} 2.5 \% \mathrm{~Pa}$ (1) 6/y.

Trait $3: \mathrm{S} / 2 \mathrm{~d} 4$ 6d/7 ET2.5\% Pa1(1) 6/y.

Trait 4: S/2 d4 6d/7 ET2.5\% Pa1(1) 10/y.

Trait 5: S/2 d5 6d/7 ET2.5\% Pa1(1) 10/y.

Trait 6: S/2 d6 6d/7 ET2.5\% Pa1(1) 12/y.

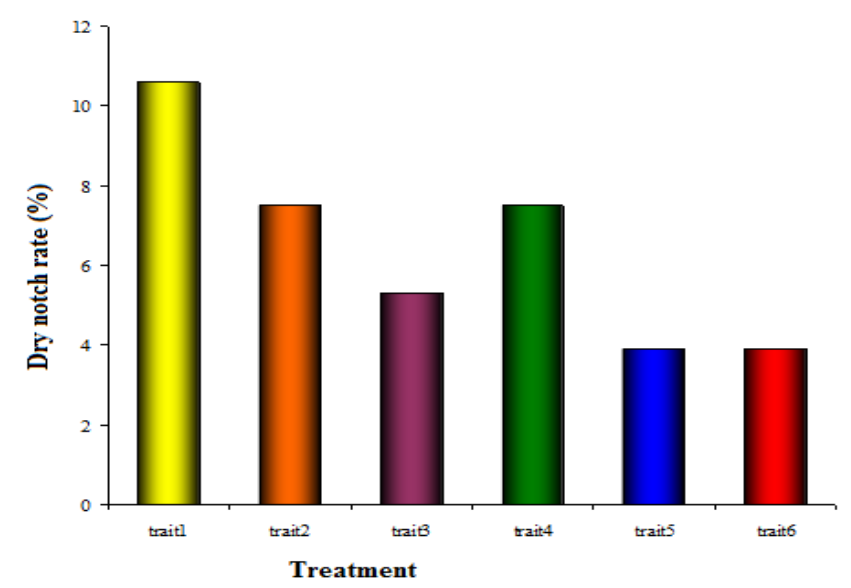

Fig. 6: Tapping panel dryness rate of Hevea brasiliensis clone RRIC 100, from the moderate metabolic class, in the south-western region of Côte d'Ivoire after nine years of latex harvesting in downward tapping on virgin bark of the lower panel.

Trait: treatment.

Trait $1: \mathrm{S} / 2 \mathrm{~d} 2$ nil stimulation.

Trait $2: \mathrm{S} / 2 \mathrm{~d} 36 \mathrm{~d} / 7 \mathrm{ET} 2.5 \% \mathrm{~Pa} 1$ (1) 6/y.

Trait $3: \mathrm{S} / 2 \mathrm{~d} 4$ 6d/7 ET2.5\% Pa1(1) 6/y.

Trait 4: S/2 d4 6d/7 ET2.5\% Pa1(1) 10/y.

Trait 5: S/2 d5 6d/7 ET2.5 \% Pa1(1) 10/y.

Trait 6: S/2 d6 6d/7 ET2.5\% Pa1(1) 12/y.

\section{3) Clone BPM 24}

Fig. 7 shows the percentage tapping panel dryness(TPD) rate generated by each treatment applied to trees of Hevea brasiliensis clone BPM 24 in southwest Côte d'Ivoire. The results indicated that TPD rates were low $(\leq 1.8 \%)$ regardless of treatment. The highest TPD rate was obtained with trees in pattern $4(1.9 \%)$ while the lowest rate was obtained with those in treatment $5(0.4 \%)$. For the same tapping frequency (d4) of treatments $3(1.1 \%)$ and $4(1.9 \%)$, the highest TPD rate was obtained with the second treatment mentioned. On the other hand, for the same level of stimulation (10/y) applied to latex harvesting technologies 4 and 5, the TPD 
rate was higher with pattern $4(1.9 \%)$ than with treatment 5 $(0.4 \%)$.

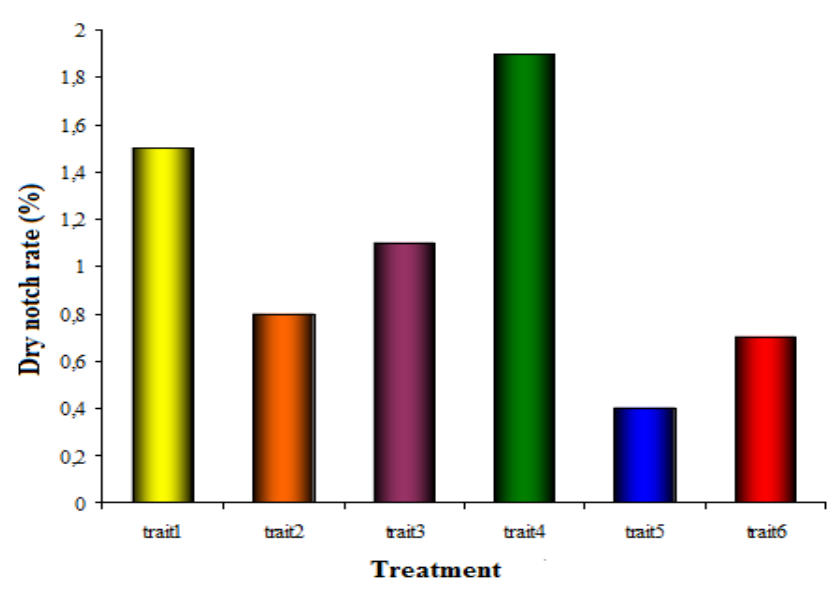

Fig. 7. tapping panel dryness rate of Hevea brasiliensis clone BPM 24, of the moderate metabolism class, in the south-western region of Côte d'Ivoire after nine years of latex harvesting in downward tapping on virgin bark of

Trait: treatment. the low panel.

Trait $1: \mathrm{S} / 2 \mathrm{~d} 2$ nil stimulation.

Trait 2 : S/2 d3 6d/7 ET2.5\% Pa1(1) 6/y.

Trait $3: \mathrm{S} / 2 \mathrm{~d} 4$ 6d/7 ET2.5\% Pa1(1) 6/y.

Trait 4: S/2 d4 6d/7 ET2.5\% Pa1(1) 10/y.

Trait 5: S/2 d5 6d/7 ET2.5\% Pa1(1) 10/y.

Trait 6: S/2 d6 6d/7 ET2.5\% Pa1(1) 12/y.

4) Average tappinf panel dryness rate of all three clones GT 1, RRIC 100 and BPM 24

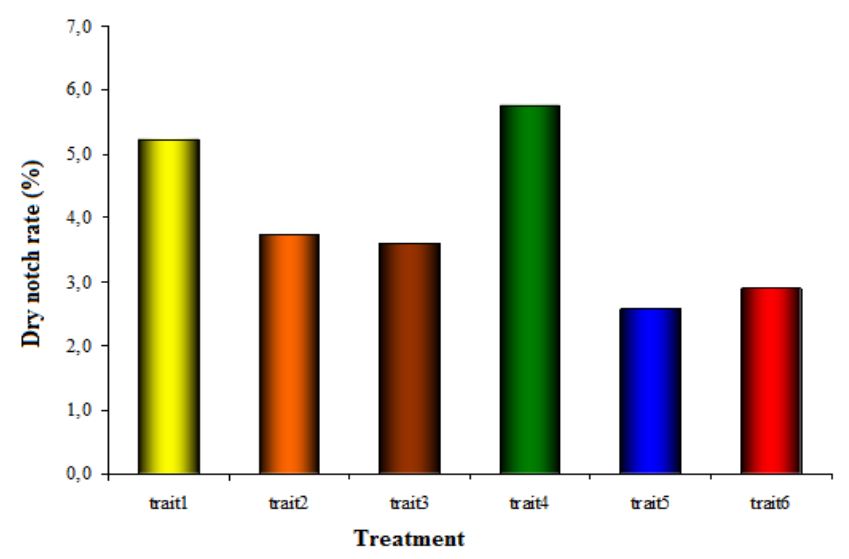

Fig. 8. Tapping panel dryness rate of trees of the GT 1, RRIC 100 and BPM 24 clones of Hevea brasiliensis, of the moderate metabolic class, in the south-western region of Côte d'Ivoire after nine years of latex harvesting in downward tapping on virgin bark of the lower panel.

Trait: treatment.

Trait $1: \mathrm{S} / 2 \mathrm{~d} 2$ nil stimulation.

Trait $2: \mathrm{S} / 2 \mathrm{~d} 3$ 6d/7 ET2.5\% Pa1(1) 6/y.

Trait $3: \mathrm{S} / 2 \mathrm{~d} 4$ 6d/7 ET2.5\% Pa1(1) 6/y.

Trait 4: S/2 d4 6d/7 ET2.5\% Pa1(1) 10/y.

Trait 5: S/2 d5 6d/7 ET2.5\% Pa1(1) 10/y.

Trait 6: S/2 d6 6d/7 ET2.5\% Pa1(1) 12/y.

Fig. 8 shows the percentage of tapping panel dryness (TPD) rate generated by each treatment applied to trees of the Hevea brasiliensis clones GT 1, RRIC 100 and BPM 24 in southwestern Côte d'Ivoire. In general, TPD rates were moderate for all treatments. These rates ranged from $2 \%$ to $6 \%$. Treatment $4(\mathrm{~d} 4-10 / \mathrm{y})$ produced the highest rate of TPD with $5.8 \%$, while the lowest rate was obtained with trees in patterns $5(2.5 \%)$ and $6(2.9 \%)$. For trees tapped at the same frequency $\mathrm{d} 4$, such as those in treatments $3(3.6 \%)$ and 4
$(5.8 \%)$, the TPD rate was higher with treatment 4 . For the same level of 10/y stimulation, latex harvesting technologies $4(5.8 \%)$ and $5(2.6 \%)$, tapping panel dryness rates were higher with treatment 4 .

\section{DISCUSSION}

The clones of the moderate metabolism class used in our study were productive, but less so than the active metabolism class. However, they were less productive than those of the active metabolism class. Of the three clones studied, the BPM 24 clone was the most productive with $2122 \mathrm{~kg} \cdot \mathrm{ha}^{-1} \cdot \mathrm{yr}^{-1}$. The GT 1 and RRIC 100 clones had the same level of average dry rubber production with respectively $1949 \mathrm{~kg} \cdot \mathrm{ha}^{-1} \cdot \mathrm{yr}^{-1}$ and $1948 \mathrm{~kg} \cdot \mathrm{ha}^{-1} \cdot \mathrm{yr}^{-1}$. In general, whatever the clone and the treatment, the yields were equivalent except for the S/2 d6 6d/7 ET2.5\% Pa1(1) $12 / y$ treatment which gave a lower yield. This could be explained by low latex harvesting intensity due to low bleeding frequency (d6) and low stimulation regime. Yields were higher when trees were tapped every three days and stimulated six times a year $(\mathrm{S} / 2 \mathrm{~d} 3$ 6d/7 ET2.5 \% Pa1(1) $6 / y)$; i.e., an average production of $4677 \mathrm{~g} \cdot \mathrm{t}^{-1} \cdot \mathrm{yr}^{-1}$ and $2145 \mathrm{~kg} \cdot \mathrm{ha}^{-1} \cdot \mathrm{yr}^{-1}$. The average production per tree and per tapping of the three clones varied and fluctuated around 50 g. $\mathrm{t}^{-1} \cdot \mathrm{t}^{-1}$. Clone BPM 24 gave the highest average production with $61 \mathrm{~g} \cdot \mathrm{t}^{-1} \cdot \mathrm{t}^{-1}$ followed by clone RRIC 100 with $56 \mathrm{~g} \cdot \mathrm{t}^{-1} \cdot \mathrm{t}^{-1}$ and finally clone GT $1,33 \mathrm{~g} \cdot \mathrm{t}^{-1} \cdot \mathrm{t}^{-1}$. For all the clones in this class, although they were tapped at the same frequency, $\mathrm{d} 4$, the increase in the number of annual stimulations (from 6 to 10) had no effect on production per tree and per tapping. This equivalence between productions is the expression of the compensation between latex harvesting intensity and stimulation regime (Soumahin, 2010). It is therefore likely that for a given tapping frequency, a margin of annual stimulations would correspond. Furthermore, when the number of annual stimulations is multiplied by 2 , i.e., from 6 to $12 / y$, and the tapping frequency is reduced by half from d3 $6 d / 7$ to $d 66 d / 7$, there is a loss of production of 415 $\mathrm{kg} \cdot \mathrm{ha}^{-1} \cdot \mathrm{yr}^{-1}$, which is compensated by a gain in radial vegetative growth. This indicates that the clones in this class are favorable for reduced tapping frequency. Although the increase in tapping intensity and the number of annual stimulations have an effect on rubber production, the fact remains that limits that the plant can tolerate must be set to avoid saturation of the laticifers functions, which are responsible for the drop in latex production (Gohet, 1996; Soumahin, 2010). These limits depend on the physiological state of the rubber tree and especially its metabolism. Beyond this determined stimulation regime, any increase in the number of stimulations is detrimental to rubber production (Gohet, 1996; Soumahin, 2010).

Regardless of the clone, a depression was observed in the radial vegetative growth of rubber trees with the latex harvesting technology S/2 d3 6d/7 ET2.5\% Pa1(1) 6/y. The correlation between radial vegetative growth potential and rubber production is always negative (Obouayeba et al., 1996b; Tjarsadihardja, 1998; Ballo et al., 2019). Our results on the radial vegetative growth of clones of the moderate metabolism class indicate the important influence of the number of stimulations as various authors have noted 
Obouayeba et al. (2008), Obouayeba et al. (2009a) and Moro et al. (2021). It is therefore necessary to use stimulant coatings sparingly when treating clones in this class, with a view to ensuring optimal growth of the rubber trees.

With regard to susceptibility to TPD, tapping panel dryness rates were low for clones in this class. The results indicate that, in general, TPD rates were highest with the S/2 d4 6d/7 ET2.5 \% Pa1(1) 10/y treatment regardless of clone. Of the three clones studied in the moderate metabolic class, the highest rates of TPD were observed in RRIC 100.

The trees most affected by this physiological dysfunction are those grown in the $S / 2 \mathrm{~d} 2$ nil stimulation pattern. In contrast to the GT 1 clone, intensification of latex harvesting by tapping frequency in the RRIC 100 clone led to an increase in the rate of tapping panel dryness (Obouayeba et al., 2021), while a reduction in tapping intensity resulted in low sensitivity to this anomaly (Soumahin, 2010). The BPM 24 clone was less sensitive to TPD than the GT 1 and RRIC 100 clones. However, for the same tapping frequency, d4, the considerable increase in stimulation intensity from 6 to $10 / y$ certainly led to saturation of the laticogenic functions (Gohet, 1996) and consequently to an increase in the TPD rate. This phenomenon would therefore be at the root of the increase in the TPD rate in rubber trees exploited according to the $\mathrm{S} / 2 \mathrm{~d} 46 \mathrm{~d} / 7 \mathrm{ET} 2.5 \% \mathrm{~Pa}(1) 10 / \mathrm{y}$ pattern. In this context, a moderate stimulation according to the tapping frequency favors an optimal functioning of the lactiferous systems and consequently a low impact on the sensitivity to tapping panel dryness. Therefore, in a situation where the availability of tapper labor is not guaranteed, the following latex harvesting technologies can be recommended for efficient latex harvesting of clones in this class:

- S/2 d3 6d/7 ET2.5\% Pa1(1) 6/y in the context where there is no problem with the availability of labour;

- S/2 d4 6d/7 SD2.5\% Pa1(1) 6/y in the case of an estimated $25 \%$ labour shortage;

- S/2 d5 6d/7 SD2.5 \% Pa1(1) 10/y in a situation of estimated $33 \%$ labour shortage.

- S/2 d6 6d/7 SD2.5\% Pa1(1) 12/y in the case of an estimated labour shortage of $50 \%$.

\section{CONCLUSION}

Rubber farmers have two concerns inherent in modern plantation management. The first concerns the processes or technologies to be developed to make the best use of the rubber production potential of elite clones with moderate metabolisms (GT 1, RRIC 100 and BPM 24). The second concerns the availability and cost of labour for tappers. To address these two concerns, we undertook a series of studies over a period of nine years in the south-west of Côte d'Ivoire. Our study was carried out according to the latex harvesting system where tapping was carried out in a descending half-spiral. It was also conducted on Hevea brasiliensis clones of moderate metabolic activity class. The results obtained have just been discussed around the influence of different latex harvesting technologies on:

$\diamond$ the production of dry rubber;

$\diamond$ the tapping panel dryness rate;

$\diamond$ the radial vegetative growth of rubber trees.

The average annual yields were indeed, for all clones combined, higher than $1700 \mathrm{~kg} \cdot \mathrm{ha}^{-1} \cdot \mathrm{year}^{-1}$; one of the best values in the world. They corroborate the fact that all clones of the active and moderate metabolic classes adapt well to a very significant reduction in tapping intensity (d6). On the basis of our results, it is therefore possible to reduce the intensity of tapping if necessary and even to respond to the unavailability and/or high cost of tapping labour. In fact, whatever the plantation management method, if the unavailability and/or high cost of tappers is 25 and $37.5 \%$, tapping frequencies $\mathrm{d} 3, \mathrm{~d} 4, \mathrm{~d} 5$ and $\mathrm{d} 6$ are the most appropriate and can be applied. If, on the other hand, the unavailability and/or dearth of tappers is $50 \%$, then only tapping frequency d6 cannot be applied to slow-metabolism clones because it gives low yields. These results show that no latex harvesting technology is bad. Everything depends on the behaviour of the user of the technology, the use he makes of it, and above all the problem he wants to solve.

Our results on the radial vegetative growth of rubber trees in the latex harvesting systems studied are remarkable. The unstimulated control shows the highest vegetative growth during tapping. These radial vegetative growth results are influenced by two factors: the tapping intensity and the stimulant, namely ethephon.

Compared to the TPD syndrome, our results showed that the sensitivity to TPD was, overall, moderate. These results show that intensification of latex harvesting (high frequency of tapping and/or high stimulation) generates and/or increases, regardless of the clone, susceptibility to dry rot. Our results are not in favour of the $\mathrm{d} 2$ tapping frequency in the recommendations for latex harvesting technologies for clones popularised in Côte d'Ivoire. Similarly, they lead to the conclusion that clones with moderate metabolism cannot be stimulated by downward tapping 10 times a year at the $\mathrm{d} 4$ tapping frequency.

\section{ACKNOWLEDGMENT}

We are grateful to the management team of the National Agricultural Research Center (CNRA) for the opportunity to conduct this study.

\section{CONFLICT OF INTEREST}

The authors declared no conflict of interest.

\section{REFERENCES}

Anonymous (1993). Recueil de fiches de clones d'Hévéa. CIRAD-Cultures pérennes, Ed., Montpellier, France, 20 p.

Ballo, E. K., Soumahin, E. F., Diarrassouba, M., Adou, B. Y. C., Kouadio, Y. J. \& Obouayeba, S. (2019). Effect of planting date on the agrophysiological parameters of clone GT 1 of Hevea brasiliensis Muell. Arg in southwestern Côte d'Ivoire. International Journal of Applied Research, 5(2), 51-58.

Brou, Y. T. (2005). Climat, mutations socio-économiques et paysages en Côte d'Ivoire. Mémoire de synthèse des activités scientifiques présenté en vue de l'obtention de l'habilitation à diriger des recherches, Université des Sciences et Technologies de Lille, 213 p.

Chapuset, T. (2001). Description des clones étudiés à grande échelle, Rapport CNRA-HEVEA n01/01 - A- Mai 2001, 36P.

Commere, J., Eschbach, M., Lacrote, R. \& Serres, E. (1988). Results of trials on reducing tapping frequency in Côte d'Ivoire, In: CR colloque sur Exploitation, Physiologie Amélioration de Hévéa J. L Jacob et J. C. Prévôt eds IRCA-CIRAD Montpellier, France, pp. 321-333. 
Coulibaly, L. F., Diarrassouba, M., Obouayeba, S., Yapi, G. C. V. \& Ake, S. (2011). Système d'exploitation en saignée inversée du clone PB 235 d'Hevea brasiliensis en Côte d'Ivoire, Journal of Animal \& plant Science, 9 (2), 1147-1160.

Eldin, M. (1971). Le climat. In: Le milieu Naturel de la Côte d'Ivoire, Mémoires ORSTOM, 5, 77-108.

Eschbach ,J.M., Roussel, D., Van De Sype, H. \& Jacob, J. L. (1984). Relationships between yield and clonal physiological characteristics of latex from Hevea brasiliensis, Physiologie Végétale, 22, 295-304.

Gohet, E. (1996). La production de latex par Hevea brasiliensis. Relation avec la croissance. Influences de différents facteurs: Origine clonale, stimulation hormonale, réserves hydrocarbonées, Thèse de doctorat d'université, Université Montpellier II, Sciences et Techniques du Languedoc, France, 343 p.

Gohet, E., Lacrotte, R., Obouayeba, S. \& Commere, J. (1991). Tapping system recommended in West Africa, In: Proceedings, RRIM Rubber grower's conference 1991, 235-254.

Gohet, E., Prevot, J.C., Eschbach, J. M., Clement, A. \& Jacob, J. L. (1996). Clone, Croissance et stimulation, facteurs de la production de latex, Plantations, Recherche, Développement, 3 (1), 30-38.

Jacob J. L., Eschbach, J. M., Prévôt, J. C., Roussel, D., Lacrotte, R., Chrestin, H., et al. (1985). Physiological basis for latex diagnosis of the functioning of the laticiferous system in rubber trees, Proceedings International Rubber Conference Rubber Research Institute Malaysia; ed. Kuala Lumpur, Malaisie, 1985.

Jacob, J. L., d'Auzac, J., Prevot, J. C. \& Serier, J B. (1995). Une usine de caoutchouc naturel: l'hévéa, Recherche, 276, 538-545.

Lukman, (1983). Revised International Notation for Exploitation for Exploitation Systems. Journal of Rubber Research Institute of Malaysia, 31, 130-140.

Moro, A. P., Adou, B. Y. C., Diarrassouba, M., Konan, D., Soumahin, E. F, Kouakou, H. T. et al. (2021). Quantitative Assessment of the Agrophysiological Advantages of Upward Tapping in Relation to the Downward Tapping of the GT 1 and PB 260 Rubber Clones [Hevea brasiliensis, Muell. arg.(Euphorbiaceae)] in Southwest Côte d'Ivoire. Journal of Experimental Agriculture International, 43(2), 94-104.

Obouayeba, S. Boa, D. \& Jacob, J. L. (1996b). Les performances du clone d'hévéa PB 217 en Côte d'Ivoire, Plantation, Recherche, Développement 3(5), 346-354.

Obouayeba, S., Coulibaly, L. F., Gohet, E., Yao, T. N., \& Ake, S. (2009a). Effect of tapping systems and height of tapping opening on clone PB 235 agronomic parameters and its susceptibility to tapping panel dryness in south-east of Côte d'Ivoire, Journal of Applied Bioscience, 24, 1535-1542.

Obouayeba, S., Konan, D., Diarrassouba, M., Lehi, M. I., Koffi, A., Ballo, E. K., et al. (2021). Relationship between the Intensity of Latex Harvesting and the Tapping Panel Dryness Expression of Clone GT 1 of Hevea brasiliensis Muell Arg in South-East Côte d'Ivoire. Journal of Advances in Biology \& Biotechnology, 24(5), 36-45.

Obouayeba, S., Soumahin, E. F., Boko, A. M. C., Dea, G. B., Dian, K. \& Gnagne, Y. M. (2008). Improvement of productivity of rubber trees in smallholding by the introduction of upward tapping in the south-east of Côte d'Ivoire. Journal Rubber Research, 11(3), 163-170.

Perraud, A. (1971). Les sols, In: Le milieu Naturel de la Côte d'Ivoire, Mémoire ORSTOM, 50, 269-390.

Prevot, J. C., Jacob, J. L., Lacrotte, R.; Clement-Vidal, A., Serres, E., Eschbach, J., et al. (1986). Physiological parameters of latex from Hevea brasiliensis. Their use in the study of the laticiferous system Typology of functioning production metabolism effects of stimulation, International Meeting; Physiology, Exploitation International Rubber Research Development Board, Hainan, Chine, 1986, $155 \mathrm{p}$.

Rajagopal, R., Vijayakumar, K.R., Thomas, K. U. \& Karunaichamy, K. (2003). Yield response of Hevea brasiliensis (clone PB 217) to low frequency tapping, Proceedings of the international workshop on Exploitation Technology, India, pp. 127-139.

Roose, E. \& Cherroux, M. (1966). Les sols du bassin sédimentaire de Côte d'Ivoire, Cahier ORSTOM, Série Pédologie 5 (2), 51-91.

Sahabane, T. M., Diarrassouba, M., Koffi, M. O., Dick, K. E., Soumahin, E. F., Coulibaly, L. F. \& Obouayeba, S. (2011). Long-term effect of different annual frequencies of ethylene stimulation on rubber productivity of clone GT 1 of Hevea brasiliensis (Muell. Arg.) in South East of Côte d'Ivoire, Agriculture Biology Journal of North America, 2(8), 1251-1260.

Sekhar, A. C. (1989). Rubberwood production and utilization, Rubber Research Institute of India, Kottayam, India, pp. 99-110.

Soumahin, E. F. (2010). Optimisation des systèmes d'exploitation en hévéaculture par la réduction des intensités de saignées, Thèse de doctorat d'université, Université de Cocody, Abidjan, Côte d'Ivoire $189 \mathrm{p}$.

Soumahin, E. F., Obouayeba, S. \& Anno, A. P. (2009). Low frequency with hormonal stimulation on Hevea brasiliensis clone PB 217 reduces tapping manpower requirement, Journal of Animal and Plant Science, 2 (3), 109-117.

Soumahin, E. F., Obouayeba, S., Dick, K. E., Dogbo, D. O. \& Anno, A. P. (2010). Low intensity tapping systems applied to clone PR 107 of Hevea brasiliensis (Muell. Arg.): Results of 21 years of exploitation in Southeastern Côte d'Ivoire, African Journal of Plant Science, 4(5), $145-153$.

Thomas, K. U., Vijayakumar, K. R., Rajagopal, R. \& Karunaichamy, K. (2003). Crop harvesting through mini and reduced spiral tapping cuts in Hevea brasiliensis, In: IRRDB International workshop on Exploitation Technology, Rubber Research Institute of India, Kottayam, India, pp. 72-82.

Tjarsadihardja, A. (1988). Low intensity tapping with stimulation on GT1. Compte rendu du colloque Exploitation Physiologie et amélioration de l'Hevea, Colloque Hevea 88 de l'IRRDB, tenu du 2 au 7 Novembre 1988 à Paris, pp. 573-586.

Van De Sype, H. (1984). The dry cut syndrome in Hevea brasiliensis, evolution, agronomical and physiological aspects, In: Compte Redu Colloque IRRDB Physiologie Exploitation Amélioration Hévéa, IRCA-CIRAD, Ed., Montpellier, pp. 227-249.

Vijayakumar, K. R., Gohet, E., Thomas, K. U., Xiaodi, W., Sumarmadji, L., Rodrigo, D., et al. (2009). Revise international notatum for latex production technology, International Rubber Research and development Board, 19 p.

Vijayakumar, K. R., Thomas, K. U., RajagopaL R. \& Karunaichamy K. (2003). Response of Hevea clone to low frequency tapping, Proceedings of the international work on Exploitation Technology, India, pp. 17-42. 